\title{
Power, Violence, Citizenship and Agency
}

\author{
Rosemary McGee
}

\begin{abstract}
Peace-building, state-building and democratisation efforts often focus strongly on the state, and follow the Weberian logic of states holding the monopoly of the legitimate use of violence. In doing so, they may be neglecting more recent and nuanced understandings of the nature of governance arrangements in fragile and conflict settings, and of the range and scope of citizen agency both in general and in such settings. This article presents a research programme on Power, Violence, Citizenship and Agency, which sets out to counter the state-heavy or at best 'CSO-heavy' approach of many aid agencies and peace-building change agents. Through a fresh look at relevant literature and theory and case studies in five settings marked by violent conflict, the programme seeks to construct the conceptual clarity and synergies that are needed to underpin shifts towards more citizen-centred perspectives among aid and change agents working in situations of chronic violence and fragility.
\end{abstract}

\section{Introduction}

The state-building and peace-building agenda has attained high prominence among aid agencies in recent years, as a range of circumstances drive donors to focus increasingly on fragile and conflict-affected states (FCAS). During the same period, in many middle-income and less aid-dependent countries of Latin America and the Middle East, where absolute poverty is not such a concern for governments or donors, inequalities in income, wellbeing and access to rights have increased to unprecedented extremes, accompanied by alarming escalations of violent conflict. Many of these countries are at more advanced stages of democratisation than the heavily aid-dependent ones with high levels of absolute poverty, and they tend not to be thought of as fragile states.

Within the state-building and peace-building agenda, 'civil society' appears as a prominent set of benign and constructive allies in pursuit of peace and democracy objectives. This is problematic. To start with, the term 'civil society' is widely regarded as a buzzword, an export of Western donors (Lewis 2002: 569) which '[means] everything to everyone remotely interested in it' (Chandhoke 2007: 608). As such, Chandhoke goes on, 'it is vital to disentangle normative expectations from the analysis of actually existing civil societies' (2007: 613). In fragile settings where violent conflict has spawned social divisions, 'civil society' actors will probably mirror these divisions in their roles as representatives of people's interests and as outreach to particular sectors of the population, thereby reinforcing societal fissures and social exclusion.

Then there are those citizens who do not form part of readily recognisable and readily engaged 'civil society'. In conflict and post-conflict situations, these less organised citizens are easily obscured and marginalised by the organised, prominent non-governmental organisations (NGOs) that emerge in response to humanitarian assistance, often in the image and likeness of international NGOs that seek familiar-looking partners. A recent review of literature on citizen participation in violent conflict settings (Oosterom 2014a), purposefully looking beyond the familiar forms of 'civil society', highlights how violent conflict affects not only states and institutions but also citizens, the interfaces between citizens and states, and the spaces in which citizenship is exercised. It observes how in violent conflict settings governance arrangements often emerge which include armed non-state actors, and which assume certain 
functions of the state, challenging the state's legitimacy, competing for authority and mediating between states and citizens (ibid.: 21). Violent conflict, it has been noted, transforms existing forms of social and political organisation as well as generating new forms (Justino 2012).

'Working with civil society in fragile states' is, then, a lot more complicated than it first appears (Dowst 2009). The assumptions about 'civil society' in the contemporary state-building and peace-building agenda beg questions. There is a need to cast off the normative expectations and explore the actual nature, organisational forms and behaviour of citizens within such settings, and the extent to which these match the assumptions.

Prompted by these questions, a group of researchers initiated the Power, Violence, Citizenship and Agency (PVCA) programme, which argues for aid agencies and change agents to shift from a state-heavy or at best 'CSO-heavy' to a more citizen-centred perspective when working in situations of chronic violence and fragility. ${ }^{1}$ Through a series of qualitative research and action-research case studies at local levels in five diverse violent settings, we problematise reallife processes as they play out beyond the confines of conventionally defined 'civil society', and beyond the usual field of vision of official aid agencies. We seek to deepen understandings of citizens' individual and collective exercise of agency to engage with the conflict or with each other in relation to the conflict in local-level governance and social processes, to exercise social leadership, and to confer legitimacy on others who exercise leadership.

This article presents the Power, Violence, Citizenship and Agency programme's conceptual framework, which my colleagues and I are using to bring fresh understandings to the question of how citizens experience situations of chronic violence, what they do about it and how they can best be supported in such complex settings.

First, I discuss the key concepts and issues with reference to the relevant literature. I go on to set out the conceptual framework we are using, with an emphasis on the notion of citizen agency, probably the least self-explanatory of the programme's key concepts. There follows a short section explaining the methodologies used, and a brief sketch of the five contexts in which we are working. I close with some reflections on the utility and validity of the project in these specific local settings and more broadly.

\section{Unpacking power, violence, citizenship and agency: meanings and connections}

Each of the terms in the programme's title power, violence, citizenship and agency - are big, complex concepts. In this section, I review selected literature that has shaped our thinking. The aim here is twofold. Firstly, this section establishes the necessary conceptual clarity for a discussion of how we approach these concepts and relate them to each other. While we can define quite readily how we understand power and violence, citizenship and agency require more discussion. Secondly, the review of literature lays bare the gaps and opportunities in current thinking and practice that constitute our rationale for undertaking this programme.

Power has been multiply and diversely defined. Our approach to it is closest to the definitions and notions found in political sociology, anthropology and social justice advocacy literature: 'forms' or 'faces of power' (Lukes 2005; Gaventa 1980, 2006; VeneKlasen and Miller 2002); 'expressions of power' (Rowlands 1997; VeneKlasen and Miller 2002); and 'spaces of power' (Gaventa 2006).

Rather than embracing any one of these approaches, we see them as conceptual lenses to be used selectively to illuminate, articulate or understand different elements of power relations and dynamics that can be observed or inferred in different situations.

We do not align ourselves with one definition of violence either. Our working definition of it is the multi-faceted one arrived at in the Violence, Participation and Citizenship research group of the Citizenship Development Research Centre (Citizenship DRG):

[...] we [acknowledge] diverse definitional approaches which could illuminate particular aspects of violence in the different research sites. At the theoretical level, we [draw] variously on definitions of violence as direct intentional physical hurt on the body of oneself or another; as symbolic and 'a form of power' according to Bourdieu (2004); and as cultural and structural violence, differentiated by Galtung (1969), in which premature illnesses and death can be attributed to structural 
inequalities and oppressions. We [study] violence in both its chronic and its acute manifestations and in terms of both physical and psychological intentional effects [...]. (Pearce, McGee and Wheeler 2011: 10-11; see also Pearce 2007)

To illustrate how we use the concept of citizenship in this work, let us now look to contemporary discourses and approaches to violent conflict in the aid literature. Contemporary orthodoxy among the aid community about how to break cycles of violent conflict is strongly influenced by that articulated in the World Development Report 2011. This advocated strengthening legitimate governance and institutions to provide citizen security, justice and employment (World Bank 2011: 12). The necessary institutional legitimacy is to be built by enhancing 'people's identification with the nation-state' (ibid.; Jones and Rodgers 2011: 986). The leadership required to strengthen legitimate governance and institutions is understood as 'responsible national leadership' exercised by state - or soon-to-be state - actors (World Bank 2011: 25).

This articulation, while it does at least mention people, largely keeps faith with earlier centralised and state-centric perspectives on how

governments and aid agencies should go about resolving situations of fragility and chronic violence. This formulation invites critique. It emphasises state-building at the expense of deepening democracy, and the state's capacity to limit violence at the expense of issues such as social or political inclusion, participation and representation. It does not sufficiently account for the role of the national or local state as a potential source of violence and insecurity, or recognise how local communities perforce coexist and reach accommodations with violent actors, in highly contextual governance arrangements that involve multiple non-state actors.

An alternative and refreshing perspective is provided by recent citizenship research in the inter-disciplinary field of development studies. Core in the scholarly and practitioner output of Citizenship DRG is the notion that states are not built by institutions alone (Gaventa and McGee 2010: 1; Citizenship DRC 2011). Citizens play a key role, and act in a context of complex power dynamics linking them to both institutions and to other citizens in various organisational forms.
While much of our work is within the citizenship school, we are mindful that those living amid violent conflict often lack effective or even de jure citizenship. Along with Kabeer, we challenge:

[...] the conventional political science understanding of citizenship in terms of the relationship between individuals and the state from both a sub-national (local) as well as a supra-national (global) perspective. First of all, from a sub-national perspective, it is apparent that membership of the nation state often means little to its members, compared to other forms of sub-national identities with which they identify and through which they exercise their claims and obligations (Kabeer 2005: 21).

Instead, in keeping with Kabeer, we recognise a societal understanding of the citizen as 'someone who belongs to different kinds of collective associations and defines their identity from participation activities associated with these different kinds of membership' (ibid.: 21-2). People's sense of their identity is a key element in their sense and exercise of agency (Isin and Wood 1999). The 'horizontal' view of citizenship that emerges from this empirically-grounded perspective 'stresses that the relationships between citizens are at least as important as the more traditional vertical view of citizenship as the relationship between the state and the individual' (ibid.: 23). In this vein, people's sense of citizenship is related to 'the terms on which they participate in collective life and the forms of agency they are able to exercise' (ibid.: 22), and these terms are of course shaped by their social identity in its multiple facets.

Which forms of agency, then, do people exercise in situations of violent conflict? While it has been recognised for some time that people deploy a range of coping strategies to survive such circumstances (Justino 2009), recent work offers a more refined analysis of the range of agency exercised in these settings, highlighting the fact that some forms go beyond 'coping' or 'survival' (Oosterom 2014a). In particular, if we follow Lister's (2003) position that 'citizen agency' denotes an act or issue being brought into the public realm, then we find abundant cases of citizen agency in conflict settings. Here the public realm into which issues are brought is not, or not only, the traditional governance 
relationships between citizens and state, but the emergent governance arrangements characteristic of conflict situations, in which nonstate armed actors may feature centrally.

Seen through the lenses of that perennial debate in the social sciences between 'agency' and 'structure', both violent conflict and its transformation or resolution derive from the exercise of agency as well as from the effect of structures, and probably involve governance structures, dynamics and actors at both local and national levels. Studying conflict and violence from an agency perspective locates centre stage the people who inhabit violent and conflict-prone localities, in recognition of the key role that they must play as individual and collective citizens if violence is to be managed or overcome. Much local activism and many external interventions for violence reduction and conflict transformation in these contexts rest on assumptions about citizens' agency. Their chances of effectiveness could be enhanced if a more comprehensive and grounded understanding of citizen agency in violent and post-conflict localities were available. Indeed, the very process of developing this could itself entail constructive engagement with local conflict dynamics. This conscious and deliberate act of 'seeing like a citizen' (to use a common Citizenship DRC motto) in settings of violent conflict, is key to the purpose of the PVCA programme.

The public realm which, for Lister, distinguishes citizen agency from other forms of agency, might be dominated by the state, or, in a violent conflict setting, by a non-state actor or configuration of actors. Citizen action occurs either within parameters established with or by the state or alternative non-state power-holders, or as a transgression of normal boundaries in citizens' relationships with these actors. Within a context of violence, multiple and variously legitimate political authorities or powers might operate: state, non-state, and many combinations in between, often at local-level interfaces. The kind of citizen action that interests us in the PVCA programme is individual and collective action which affects the violence or embodies a stance on it, undertaken from within a social fabric made up of families, friendships, civic groups, private companies, state structures, armed groups, faith groups, criminal networks and customary institutions. This assumes paramount importance in violent contexts because the 'social terrain' is volatile and insecure, marked by multiple authorities connected to each other by power relations in flux.

Literature on states is replete with interpretations of the Weberian conception of the state that emphasise the state's legitimate use of violence as a means of asserting authority. In a more recent departure from classic interpretations of Weber on the state, Migdal offers a 'state-in-society' model which assigns a much less exclusive role to the state in setting and enforcing the rules by which people live (Migdal 2006). Gritiquing those interpretations of Weber, Migdal points out that 'a word such as 'legitimate' diverts attention from contending forms of authority or disgruntlement with dominant forms of authority' (2006: 14). Elsewhere Migdal argues that of the three ways states achieve social control (compliance, participation and legitimation):

the most potent factor accounting for the strength of the state, legitimation, is $[\ldots]$ an acceptance, even approbation, of the state's rules of the game, its social control, as true and right. [L] egitmacy includes the acceptance of the state's symbolic configuration within which the rewards and sanctions are packaged. It indicates people's acceptance of the state's desired social order [...] (Migdal 1988: 33).

Substituting in this proposition 'the state' with the more heterodox governance arrangements characteristic of violent conflict settings, it emerges that an important power citizens have in these settings is the power of conferring legitimacy.

Barter (2012) sets out three 'strategies' that citizens can draw on when facing violence: flight, voice and support ${ }^{2}$ - different levels of citizen agency. He unpacks 'voice' into the sub-categories of defiance, everyday resistance, or engagement. This engagement essentially consists of negotiation with power-holders and 'social navigation' (Vigh 2006) of the volatile, insecure social terrain of the conflict (Oosterom 2014a). Through these practices, the rules of the game are established and played out; citizens legitimate the prevailing social order, disorderly as it may be. ${ }^{3}$ 


\section{Linking power, violence, citizenship and agency: a conceptual framework}

Following on from the foregoing exploration of key terms and concepts, this section discusses how we relate them to each other. It shows how in doing so we engage with critical perspectives on power, violence, citizenship and agency, and forge a new way of understanding their interlinkages as they apply to real-life settings.

Much recent scholarship on citizen action focuses on how citizens can be supported or strengthened to articulate their demands (see Rocha Menocal and Sharma 2008; Malena 2009; Gaventa and Barrett 2010). 'Demand-side' civil society support projects and 'accountable governance' aid programmes have been developed to further this purpose. In this vision, the key trigger to this strengthening and mobilisation process is taken to be the provision of information: information that mobilises them by telling them what they can do to fill in for state weaknesses or complement public action; information that guides them by telling them their rights and entitlements; information that galvanises them by showing how much public money is leaking and to where. Evidence is mounting, however, that citizens furnished with new information don't act when aid theory would have them act. It transpires that other factors might be necessary (see, for instance, Lieberman et al. 2013; Fox 2014).

To restate this in more academic terms: within a general consensus that citizen action is a key way to make governments more accountable or responsive to citizens' needs, two framings have dominated thinking and aid programming about active citizenship. In the 'principal-agent problem' and 'information asymmetry' framing, the provision of information has been seen as the way to trigger citizen action, for instance to demand from the state accountability over public funds, or security in the face of danger. In the 'collective action problem' framing, the provision of organisational strengthening and incentives to mobilisation have been seen as the way to reduce the costliness of citizen action for poor people, and make their demands better articulated and more effective at securing responsiveness (Devarajan, Khemani and Walton 2011; Booth and Cammack 2013).

For citizens in violent settings, firstly, the citizen action required to fulfil needs or address deficits in rights, may have to be directed not at the state but at the multiple non-state actors which form part of the emergent, contingent governance arrangements. Secondly, information may well be insufficient to unleash citizen action. One can intuit that in such settings, other essential factors might be citizens' perceptions of themselves as knowing agents rather than hapless victims; a sense that there is some point in taking action (not necessarily motivated by self-interest, but alternatively by communitymindedness, solidarity or a need for therapeutic or self-redemptive action after trauma); and, crucially, a reasonable certainty that one's action will not be punished by violence or dispossession. It is important to improve understandings of which factors shape and constrain the behaviour of citizens in violent settings - including the ways they negotiate local power dynamics.

The PVCA programme builds on the 'principalagent' and 'collective action' framings. It adds the notion that, in situations characterised by violence past or present, collective or individual action in the face of state failure to provide for and protect citizens, shaped as it is by identity, is also shaped and constrained. What constrains it is more than lack of information (as proponents of the 'principal-agent problem' would have it) or the inability to organise and mobilise efficiently and effectively (as proponents of the 'collective action problem' would have it). The programme is studying and engaging with manifestations of citizens' agency in violent settings through the lenses of power, because our experience of living and working in these contexts suggests to us that power concepts and analysis bring important additional dimensions into view. They afford the additional explanatory power that is needed to understand citizen-level dynamics in these settings, and the additional insights necessary for honing appropriate responses and support strategies.

Having set out the programme's broad purpose and approaches to power, violence, citizenship and agency, all strongly informed by our recognition of citizens as 'makers and shapers' with agency, rather than as 'users and choosers' of interventions or services designed by others (Cornwall and Gaventa 2000), we can now turn to a range of critical perspectives on violent conflict and external agents' and citizens' responses to it, which inform our work. These 
fall into two sets of critiques - one about the relationships among citizens, as distinct from those between citizens and states; and one about the relevance of the nation-state.

On the question of relationships among citizens, it is worth starting by stating the obvious: citizens are not an undifferentiated mass. From distinct and intersecting positions and identities, they act collectively and individually to protect their own, legitimise those they trust to assist them, avoid or resist those they distrust - with either 'pro-social' or 'anti-social' manifestations. This points to a major weakness in the dominant discourses on, for instance, governance reform, transparency and accountability and social innovation, which often seem addressed to citizens as 'users and choosers' rather than 'makers and shapers', and to a fairly uniform set of 'users and choosers' at that.

Traditional conceptions of governance as a dyadic relationship between state and citizens, and of governance programming as either 'supply-side' (state) or 'demand-side (citizens and CSOs), are now recognised to have outlived their use in some respects. It has been pointed out that the dynamics that take place at the interfaces between the two are as important as dynamics on either side (Fox 2005; Centre for the Future State 2010). But many marginalised citizens rarely interact directly with the state, or, in violent contexts, may only encounter the state directly in its military aspect. Their interactions with the state tend to be brokered by intermediaries, often people from within their own communities who are better connected to local power structures than they are. These may be local elites, 'small-time political fixers' (Manor 2000), agents of local political bosses. In any case, when they need to 'get through' to the state many citizens rely on local-level intermediaries; but many citizens opt to rely on each other rather than even trying to 'get through' to the state. In a context where trust has been destroyed and citizens' expectations of the state eroded by state fragility and violent conflict, the empirically-grounded concept of 'horizontal citizenship' described by Kabeer above and affirmed by others comes into its own. The most relevant interfaces and dynamics of 'governance' often lie not between citizens and state, but within the citizenry and within the community (Wheeler 2005; Justino, Leavy and
Valli 2009): between different kinds of organised social actors, between citizens and non-state actors, or indeed between shifting identities of the same actors as they move between different spaces and moments (e.g. gendered identities in public, private and intimate spaces).

To assert this is not to peddle the "myth of community'4 (Guijt and Shah 1998). Given the diversity between citizens and the peculiarities of conflict and post-conflict dynamics of trust, expectation, suspicion and sheer need, it is not surprising to find evidence that violence is used instrumentally by some groups in society to exert power over others (Arjona and Kalyvas 2009; Pearce, McGee and Wheeler 2011). Citizens can and do come to terms with whichever leader or authority seems to offer what they need, conferring social legitimacy on them and subscribing to their leadership in return for a measure of safety and predictability. Also, as individuals and collectives, they can assume social leadership roles at the local level themselves, rather than passively accepting leadership from or actively conferring legitimacy on others; and these forms of leadership can acquire considerable social legitimacy despite not being formal or official. The result is a complex web of agencies, legitimacies and formal and informal institutions, enacted by citizens and collective 'non-state actors' as much as by state actors or political leaders, 'emergent orders' of 'mediated statehood' (Raeymaekers, Menkhaus and Vlassenroot 2008). This suggests that those wishing to intervene constructively to make or keep peace therefore need to shift their attention from the national-level state to these local-level citizen-led acts of agency, legitimation and leadership.

On the relevance of the nation-state, recall that the World Development Report 2011 advocates the 'identification of citizens with the nation-state' as key to strengthening legitimate governance and institutions (World Bank 2011). While this might be one element that helps deepen democracy and engage citizens in peaceful democratic governance, it has been shown to be an insufficient condition for deepening democracy and engaging citizens in governance in a lasting way and throughout society (Coelho and von Lieres 2010). Further, it is a problematic prescription in contexts where the state itself is not in control of parts or even large swathes of 
1 In complex, violence-prone settings, a wide range of social actors react to their circumstances in a range of ways, expressed in a range of forms of expression and action (verbal and non-verbal), exercise agency and deploy strategies of engagement with state and non-state duty-bearers to realise their rights, and to prevent or transform violent conflict. They can also react and engage in a contrary spirit, in ways which foment or perpetuate violence. Theories of power from various disciplines attest to psychological and emotionally embodied effects of violence, risk and conflict which affect people's agency and personal power, for instance by undermining trust or scope for cooperative action (see for instance Varela, Thompson and Rosch 1991). Existing knowledge of this kind needs to be harnessed, to enrich the current state of power analysis scholarship and practice. Its absence from dominant theories and approaches to interventions in fragile contexts constitutes a further shortcoming and possibly a further constraint on their effectiveness.

2 In such contexts, legitimacy and leadership are conferred and constructed by citizens as well as, and sometimes more than, by the government, neighbouring states, the domestic and transnational private sector, international aid or diplomatic community. This conferral or construction of 'legitimacy from below' - or conversely, the withholding or dismantling of legitimacy - is a manifestation of individual and collective citizen agency which is not well-understood, and hence is not best supported in aid and community reconstruction programmes.

3 It is not only state actors that exercise the leadership necessary for navigating conflict and post-conflict settings. Social leadership matters too. The term social leadership does not refer to conventional state or community leaders, but to expressions of citizen action that have mobilising capacity of and among citizens, with the effect of responding to, mitigating or exacerbating conflict or violence. Social leadership is a source of agency that may confirm or disconfirm the legitimacy of powerful actors and institutions, including those that perpetrate violence. Yet what enables or constrains social leadership and its scope to emerge and work effectively in violent settings as one aspect of complex 'social navigation' is under-explored, limiting the degree to which it can be conferred wisely or supported externally.

4 The governance regime and institutions whose legitimacy needs to be confirmed and strengthened for citizens' needs and rights to be respected, may not be of the state. They may be much less formal, more local forms of authority and modus vivendi. Citizens' conferral of legitimacy on violent actors - including violent states or violent insurgents may be rational within their own terms; understanding this from citizens' perspectives could illuminate attempts to shift legitimacy from violent to non-violent actors.

5 'Civil society' and 'NGO' framings are reductionist. They obscure the fact that multiple and overlapping forms of social agency and response are at play, often operating less than visibly, formally or 'civil-ly', but critically important to questions of power, violence and agency. Exploration is needed of the interface between the social, civil and the political, in terms of the forms of agency, actors and structures of interest. This is in deliberate contrast to both lazy usage of the term 'civil society' which in fact refers to just one - readily identifiable but narrow - segment of the social fabric. It also deliberately contrasts with misleading and facile demarcations between 'civil society' and 'state' actors and spaces (political and bureaucratic but also military and security sector) that sometimes characterise analysis of such contexts.

6 Deepening the knowledge and understanding necessary for putting these insights to work is difficult given the complications, dangers and circumscriptions characterising social action and research in violent or post-violent circumstances. Appropriate epistemological and methodological approaches, and networks and experience in a range of complex and violence-prone contexts, are crucial elements in devising workable actions and processes. 
the national territory, cannot provide security for citizens and does not have a monopoly over the legitimate use of violence. This is the reality not only in fragile and conflict-affected states, but also in pockets of conflict in some relatively stable states ruled by electoral democracy of sorts. Where states are lacking in capacity or stability, citizens' expectations in terms of basic needs, employment, livelihoods, safety and responsiveness may be better fulfilled by nonstate actors. Where legality and legitimacy have been undermined by violent conflict and state incapacity to fulfil its theoretical roles, the legality of actors and actions often matters much less than their social legitimacy.

Then there is the implicit assumption that the nation-state is relevant to the marginalised urban community or the rural hamlet. In the everyday life of geographically and sociopolitically marginal places, if state legitimacy matters at all - rather than that of non-state actors, or the 'anti-state' - it is quite likely not to be that of the nation-state but of the local state to echo Kabeer's point above about the subnational state.

Moreover, the nation-state may only be relevant in that it is part of the problem. Poor and dispossessed people often perceive the state as perpetrator or accomplice of the violence visited upon them (Benequista, Barrett and McLeanHilker 2010), and the instances where this has been demonstrably so are legion.

From these critical starting points come six underpinning propositions of the PVCA programme (see Box 1). A set of research questions follows from these propositions. Phrased broadly, these have subsequently been re-worked with local research and activist partners in each case to adapt them for the local context and attune them to other programmes carried out by our partners. In this way, outcomes will be more relevant to their work:

1 How do social actors react to complex, violence-prone contexts? In such circumstances, how do they exercise agency and use citizen engagement strategies to realise their rights or transform conflict? How do their reactions confirm or negate the legitimacy of powerful actors and structures, tacitly or consciously?
2 What hinders their efforts to engage in some way with the conflict and what facilitates them? What can be gained through reflexive analysis of the roles that immersed social actors themselves and external actors seeking to support them, play in catalysing or restraining both violence, and agency to transform violence?

3 How can international social actors (aid donors, INGOs and others) interact with these expressions of agency and these strategies in the interests of violent conflict transformation and prevention?

\section{A methodology, five contexts and five cases}

The programme builds on our past work ${ }^{5}$ and arises from our perceptions and experiences of social activism and research, and of limitations in existing aid approaches to local governance issues in violent and fragile contexts, including some we have been involved in. While the research questions above are formulated by the IDS researchers involved, they are grounded in our rooted, peopled experiences in various processes and with various actors who hold stakes in this field of enquiry. We are conducting all these activities in partnerships with grounded actors and processes immersed in the contexts of interest. We are working with organisations with which we have long-established relationships, whose members and local partner organisations engage in peaceful and non-violent ways with the latent or overt violent conflict around them. Organisational and institutional capacity in relevant applied and action research is scant in Southern countries undergoing or emerging from violent conflict, and we are seeking to enhance these capacities wherever we have the scope to do so.

Our work explicitly centres not on structures nor on national-level actors but engages local-level agents - local change agents, participants in social conversations and mobilisations, individuals and collectives - as our research subjects and collaborators in this venture. We seek to engage with national-level and international-level aid actors insofar as they seek to support these agents.

The PVCA programme's overall methodology is social-constructivist and actor-oriented, and the data we gather and construct with co-researchers and participants is principally qualitative. Beyond 


\begin{tabular}{|c|c|c|}
\hline Country & Context and focus of case study & Methods \\
\hline Egypt & $\begin{array}{l}\text { Examines the causes and dynamics of violence } \\
\text { after the demise of President Mubarak up to } \\
\text { present times. Explores the extent to which } \\
\text { the political settlement that emerged in } \\
\text { February } 2011 \text { was responsible for the rising } \\
\text { violence and the ensuing revolt in June } 2013\end{array}$ & $\begin{array}{l}\text { Sequenced, mixed-method research design: } \\
\text { qualitative methods to identify key actors, } \\
\text { agendas and processes, formal and informal; } \\
\text { quantitative secondary analysis of indicators of } \\
\text { violence; survey of respondents involved in } \\
\text { revolt; and focus group discussions to } \\
\text { contextualise and nuance survey findings }\end{array}$ \\
\hline
\end{tabular}

\begin{tabular}{|c|c|}
\hline Kenya & $\begin{array}{l}\text { Focuses on how citizens live through and } \\
\text { mitigate different types of violence in Marsabit } \\
\text { County, northern Kenya, enquiring into the } \\
\text { part that endemic violence at the micro-level } \\
\text { plays in the current political settlement, } \\
\text { through exploration of day-to-day reality of } \\
\text { violence in people's experience. Based on } \\
\text { fieldwork in 2013-14 }\end{array}$ \\
\hline
\end{tabular}

Two-stage qualitative method: scoping through an informal 'listening' method (structured stratified focus group discussions), followed by deep conversations with people from different communities, of different ages and genders

\begin{tabular}{|c|c|c|}
\hline South Sudan & $\begin{array}{l}\text { Provides a gendered perspective on the } \\
\text { different forms of violence experienced by } \\
\text { people in an insecure state, post-civil-war } \\
\text { South Sudan. Agency is expressed through } \\
\text { the modification of customary institutions } \\
\text { to develop security strategies. Based on } \\
\text { fieldwork in Eastern Equatoria State in } 2013\end{array}$ & $\begin{array}{l}\text { Qualitative and participatory approach, using } \\
\text { focus group discussions, individual interviews, } \\
\text { participatory methods and participatory } \\
\text { photography }\end{array}$ \\
\hline Zimbabue & $\begin{array}{l}\text { Explores the strategies of youth in dealing } \\
\text { with political violence and repression, in their } \\
\text { individual and collective forms. It explores } \\
\text { how the repressive regime context shapes } \\
\text { the socialisation of youth and how they } \\
\text { experience their citizenship. Based on } \\
\text { fieldwork in Mashonaland and Matebeleland } \\
\text { in 2013-14 }\end{array}$ & $\begin{array}{l}\text { Qualitative and participatory approach. Focus } \\
\text { groups, interviews, participatory analysis, } \\
\text { theatre and drama }\end{array}$ \\
\hline Colombia & $\begin{array}{l}\text { Explores citizen agency in the form of several } \\
\text { overlapping citizen-led processes of resistencia } \\
\text { (resistance) to violence, variously located } \\
\text { within and without constitutionally-provided } \\
\text { spaces, in a 'post-conflict' setting of intense } \\
\text { structural and direct violence. Based on } \\
\text { fieldwork in Buenaventura in } 2014\end{array}$ & $\begin{array}{l}\text { Qualitative research and action research } \\
\text { processes, using sequence of semi-structured } \\
\text { interviews, focus group discussions with } \\
\text { different ages and genders, and exploration of } \\
\text { cultural expressions of resistance }\end{array}$ \\
\hline
\end{tabular}

Source Author's own.

that common methodological approach, the five case studies each deploy slightly different sets of methods, depending on context, researcher preference and the specific research questions of most interest. Table 1 briefly summarises the setting, focus and methods used in each case study. ${ }^{6}$

\section{Closing reflections}

To write a conclusion would be premature: the programme is ongoing, and so are the struggles and processes featured in the case studies. In 2013 and 2014, critical learning processes have been initiated and fuelled by the case study work in each of the five countries among the local researchers and activists with whom we have engaged. In September 2014 our co-researchers from each of the case studies will come together to work with us on turning experience and knowledge from the case studies into insights for constructing effective theories of change for 
external aid agencies or more local social actors aspiring to support change processes in violent settings. Subsequently a synthesis report will be produced that looks across all five cases plus the overarching theme of social leadership. This will distil the critical factors shaping citizen agency in contexts of violence, as well as sharing methodological and process aspects which we hope can then be taken up, applied and adapted by other groups and projects wishing to work on these issues in other contexts. A final knowledgesharing, dissemination and influencing event with global reach, to which we convene actors

\section{Notes}

1 The group consists of Marjoke Oosterom, Jethro Pettit, Patta Scott-Villiers, Mariz Tadros and me. Our respective case study focuses are South Sudan and Zimbabwe (Oosterom), the cross-cutting theme of social leadership (Pettit), Kenya (Scott-Villiers), Egypt (Tadros) and Colombia (McGee). This article and the project on which it is based are built on discussions, analysis and meanings co-constructed by the group. I am indebted to them, in particular to Marjoke Oosterom, whose literature reviews and convening powers have situated and nourished the project. As a team, we are also indebted to those who have funded the PVCA programme: the UK Department for International Development (DFID) - Egypt and Kenya case studies; Inter-Church Organisation for Development Cooperation (ICCO) - South Sudan case study; Hivos Zimbabwe - Zimbabwe case study; Swiss Agency for Development and Cooperation (SDC) - Colombia case study; and Hivos Knowledge Programme - action research on social leadership, and knowledgesharing component.

\section{Bibliography}

Arjona, A. and Kalyvas, S. (2009) Rebelling against Rebellion: Comparing Insurgent and CounterInsurgent Recruitment, Workshop Paper, www.kent.ac.uk/politics/carc/reading\%20group/ Arjona\%20Kalyvas\%20Mobilisation\%20for\% 20Poltiical\%20Violence.pdf (accessed 1 June 2014)

Barter, S.J. (2012) 'Unarmed Forces: Civilian Strategies in Violent Conflicts', Peace and Change 37.4: 544-69

Benequista N.; Barrett, G. and McLean-Hilker, L. (2010) 'Broadening Spaces for Citizens in Violent Contexts', Citizenship DRC Policy Briefing, engaged in peace-building and state-building, will conclude the programme in early 2015.

The convergences and contestations of citizenship, agency and power in violent settings will go on. We hope that through the action research and learning processes of PVCA we will have added clarity and strategic insight to the perspectives of some actors directly involved in them, and of some actors working in situations of chronic violence, fragile states and fragile citizenship. For this kind of research process, that will be the ultimate test of validity.

2 The term Barter uses is 'civilians' rather than 'citizens'; his typology remains fully relevant here.

3 This paragraph owes much to insights provided by Marjoke Oosterom in her feedback on a draft of this article and in her $\mathrm{PhD}$ thesis, which I gratefully acknowledge.

4 I borrow the phrase from the title of a volume edited by Irene Guijt and Meera Shah, The Myth of Community: Gender Issues in Participatory Development (1998), in which they use it to highlight how communities are neither homogeneous nor harmonious and conflict-free, focusing specifically on gender differences.

5 Particularly, but not only, within the Gitizenship DRC (www.drc-citizenship.org).

6 These context descriptions draw on my colleagues' descriptions of them in their published outputs: Tadros (2014); ScottVilliers et al. (2014); Oosterom (2014b). For details of the programme and its publications to date see www.ids.ac.uk/project/powerviolence-citizenship-and-agency.

Brighton: IDS, www.drc-citizenship.org/system/ assets/1052734708/original/1052734708hilker_etal.2010-broadening.pdf?1399029006 (accessed 1 June 2014)

Booth, D. and Cammack, D. (2013) Governance for Development in Africa; Solving Collective Action Problems, London: Zed

Centre for the Future State (2010) An Upside Down View of Governance, Brighton: IDS, www2.ids.ac.uk/futurestate/pdfs/AnUpsidedownViewofGovernance.pdf (accessed 1 June 2014)

Chandhoke, N. (2007) 'Civil Society', Development in Practice 17.4-5: 607-14 
Citizenship DRG (2011) Blurring the Boundaries: Citizen Action across States and Societies, Brighton: IDS, http://drc-citizenship.org/system/assets/ 1052734700/original/1052734700-cdrc.2011blurring.pdf (accessed 1 June 2014)

Coelho, Vera Schattan P. and von Lieres, B. (eds) (2010) Mobilizing for Democracy: Citizen Action and the Politics of Public Participation, London: Zed

Cornwall, A. and Gaventa, J. (2000) 'From Users and Choosers to Makers and Shapers:

Repositioning Participation in Social Policy', IDS Bulletin 31.4: 50-62

Devarajan, S.; Khemani, S. and Walton, M. (2011) Civil Society, Public Action and Accountability in Africa, Policy Research Working Paper 5733, Washington DC: World Bank

Dowst, M. (2009) Working with Civil Society in Fragile States, INTRAC Policy Briefing Paper 23, Oxford: International NGO Training and Research Centre (INTRAC)

Fox, J. (2014) Social Accountability: What Does the Evidence Really Say?, GPSA Global Forum, Global Partnership for Social Accountability, http://jonathanfoxucsc.files.wordpress.com/ 2012/12/fox_gpsa_forum_may_14_2014_what _does_the_evidence_really_say.pdf (accessed 1 June 2014)

Fox, J. (2005) 'Empowerment and Institutional Change: Mapping "Virtuous Circles" of StateSociety Interaction', in R. Alsop (ed.), Power, Rights and Poverty: Concepts and Connections, Washington DC: World Bank

Gaventa, J. (2006) 'Finding the Spaces for Change: A Power Analysis', IDS Bulletin 37.5: 23-33

Gaventa, J. (1980) Power and Powerlessness: Quiescence and Rebellion in an Appalachian Valley, Oxford: Clarendon Press

Gaventa, J. and Barrett, G. (2010) So What Difference Does it Make? Mapping the Outcomes of Citizen Engagement, IDS Working Paper 347, Brighton: IDS, www.drc-citizenship.org/system/ assets/1052734701/original/1052734701gaventa_etal.2010-so.pdf?1399028197 (accessed 27 June 2014)

Gaventa, J. and McGee, R. (2010) 'Introduction; Making Change Happen - Citizen Action and National Policy Reform', in J. Gaventa and R. McGee (eds), Gitizen Action and National Policy Reform: Making Change Happen, London: Zed

Guijt, I. and Shah, M.K. (1998) The Myth of Community: Gender Issues in Participatory Development, London: Intermediate Technology Publications
Isin, E.F. and Wood, P. (1999) Citizenship and Identity, Thousand Oaks CA and London: Sage Jones, G. and Rodgers, D. (2011) 'The World Bank's World Development Report 2011 on Conflict, Security and Development: A Critique through Five Vignettes', Journal of International Development 23: 980-95

Justino, P. (2012) Shared Societies and Armed Conflict: Costs, Inequality and the Benefits of Peace, IDS Working Paper 410, Brighton: IDS

Justino, P. (2009) 'Poverty and Violent Conflict: A Micro-Level Perspective on the Causes and Duration of Warfare', Journal of Peace Research 46.3: 315-33

Justino, P.; Leavy, J. and Valli, E. (2009) 'Data Collection in Violent Contexts: Methodological Challenges - Quantitative Methods in Contexts of Everyday Violence', IDS Bulletin 40.3: 41-9

Kabeer, N. (2005) 'Introduction: The Search for Inclusive Citizenship - Meanings and Expressions in an Inter-connected World', in N. Kabeer (ed.), Inclusive Citizenship: Meanings and Expressions, London: Zed

Lewis, D. (2002) 'Civil Society in African Contexts: Reflections on the Usefulness of a Concept', Development and Change 33.4: 569-86

Lieberman, E.; Posner, D. and Tsai, L. (2013) Does Information Lead to More Active Citizenship? Evidence from an Education Intervention in Rural Kenya, http://web.mit.edu/posner/www/papers/ LPT\%20slides\%2024\%20Jan\%2013.pdf (accessed 1 June 2014)

Lister, R. (2003) Citizenship. Feminist Perspectives, Basingstoke: Palgrave Macmillan

Lukes, S. (2005) Power: A Radical View, 2nd ed., London: Macmillan

Malena, C. (ed.) (2009) From Political Will to Political Won't: Building Support for Participatory Governance, Sterling VA: Kumarian Press

Manor, J. (2000) 'Small-time Political Fixers: Towel over Armpit', Asian Survey 40.5: 816-35

Migdal, J.S. (2006) State in Society: Studying How States and Societies Transform and Constitute One Another, Cambridge: Cambridge University Press

Migdal, J.S. (1988) Strong Societies and Weak States: State-Society Relations and State Capabilities in the Third World, Princeton NJ: Princeton University Press

Nordstrom, C. (1997) A Different Kind of War Story, University of Pennsylvania Press

Oosterom, M. (2014a) 'The Effects of Violent Conflict and Displacement on Citizen Engagement: A Case Study from Northern 
Uganda', $\mathrm{PhD}$ thesis, Institute of

Development Studies, University of Sussex

Oosterom, M. (2014b) 'It May Approach as Quickly as a Bushfire': Gendered Violence and Insecurity in South Sudan, IDS Research Report 78, Brighton: IDS, www.ids.ac.uk/publication/itmay-approach-as-quickly-as-a-bushfiregendered-violence-and-insecurity-in-south-sudan (accessed 1 June 2014)

Pearce, J. (2007) Violence, Power and Participation: Building Citizenship in Contexts of Chronic Violence, IDS Working Paper 274, Brighton: IDS

Pearce, J.; McGee, R. and Wheeler, J. (2011) Violence, Security and Democracy: Perverse Interfaces and their Implications for States and Citizens in the Global South, IDS Working Paper 357, Brighton: IDS

Petersen, R.D. (2001) Resistance and Rebellion. Lessons from Eastern Europe, Cambridge:

Cambridge University Press

Raeymaekers, T.; Menkhaus, K. and Vlassenroot, K. (2008) 'State and Non-state Regulation in African Protracted Crises: Governance without Government?', Africa Focus 21.2: 7-21

Rocha Menocal, A. and Sharma, B. (2008) Joint Evaluation of Citizens' Voice and Accountability: Synthesis Report, London: Department for International Development (DFID)

Rowlands, J. (1997) Questioning Empowerment: Working with Women in Honduras, Oxford: Oxfam Scott-Villiers, P.; Ondicho, T.; Lubaale, G.;

Ndung'u, D.; Kabala, N. and Oosterom, M. (2014) Roots and Routes of Political Violence in Kenya's Civil and Political Society: A Case Study of Marsabit County, IDS Evidence Report 57, Brighton: IDS, http://opendocs.ids.ac.uk/ opendocs/bitstream/handle/123456789/3963/ ER71\%20Roots\%20and\%20Routes\%20of\%20 Political\%20Violence\%20in\%20Kenya\%E2\% 80\%99s\%20Civil\%20and\%20Political\%20 Society\%20A\%20Case\%20Study\%20of\%20 Marsabit\%20County.pdf?sequence $=1$ (accessed 27 June 2014)

Tadros, M. (2014) Settling After the Revolts?' Egypt's Political Settlements and Violent Transition, IDS Evidence Report 57, Brighton: IDS, http:/opendocs.ids.ac.uk/opendocs/bitstream/ handle/123456789/3545/ER57\%20Settling\% 20After\%20the\%20Revolts\%20Egypt\%E2\% 80\%99s\%20Political\%20Settlements\%20and $\% 20$ Violent $\% 20$ Transition.pdf? sequence $=1$ (accessed 27 June 2014)

Varela F.J.; Thompson E. and Rosch, E. (1991) The Embodied Mind: Cognitive Science and Human Experience, Cambridge MA: MIT Press

VeneKlasen, L. and Miller, V. (2002) A New Weave of Power, People and Politics: The Action Guide for Advocacy and Citizen Participation, Bourton on Dunsmore UK: Practical Action Publishing Vigh, H. (2006) Navigating Terrains of War: Youth and Soldiering in Guinea-Bissau, Oxford: Berghahn

Wheeler, J. (2005) 'Rights without Citizenship? Participation, Family and Community in Brazil', in N. Kabeer (ed.), Inclusive Citizenship, London: Zed Books

Wood, E. (2008) 'The Social Processes of Civil War: The Wartime Transformation of Social Networks', Annual Review of Political Science 11: 539-61

World Bank (2011) Word Development Report 2011: Conflict, Security, and Development, Washington DC: World Bank 